International Journal of Engineering \& Technology, $7(2.23)(2018) 516-518$
International Journal of Engineering \& Technology
SPC
Website $:$ www.sciencepubco.com/index.php/IJET
Research paper

\title{
Automation of Work Processes at Ukrainian Sorting Stations
}

\author{
Strelko Oleh ${ }^{1 *}$, Kyrychenko Hanna ${ }^{2}$, Berdnychenko Yulia $^{3}$, Hurinchuk Svitlana ${ }^{4}$ \\ ${ }^{1}$ State University Of Infrastructure And Technology, 9, Kyrylivska St., Kyiv, Ukraine, 04071 \\ ${ }^{2}$ State University Of Infrastructure And Technology, 9, Kyrylivska St., Kyiv, Ukraine, 04071 \\ ${ }^{3}$ State University Of Infrastructure And Technology, 9, Kyrylivska St., Kyiv, Ukraine, 04071 \\ ${ }^{4}$ State University Of Infrastructure And Technology, 9, Kyrylivska St., Kyiv, Ukraine, 04071 \\ *Corresponding Author E-Mail: Olehstrelko@Gmail.Com
}

\begin{abstract}
The article analyses the existing options for improving sorting stations operation by implementing informational support and automated systems as well as the development of new ideas to solve this issue. The study of this theme makes it possible to improve all basic indicators of station operation, the directorate and the railway as a whole. This study is a scientific problem to be reasonably considered with a systematic approach. The problem of sorting stations description as a complex facility of automation in the design systems of unified automated control systems has been considered. The analysis of up-to-date information systems and technologies being utilized at sorting stations of Ukraine has been carried out. Functional capabilities to be achieved while integration of the "Automated control system" into the ASFTO UZ - (e) have been achieved. Directions for further development of automated subsystem "Dynamic work of the railway junction" requiring scientific researches in solving complex tasks for providing communication between the station wagon and the departure (transport document) have been determined. It has been determined that the further development of automated subsystem "Dynamic work of the railway junction" was impossible without interaction with the feeder lines model, because all sorting stations perform a large amount of work with the participation of feeder lines.
\end{abstract}

Keywords: Sorting Station, Information Systems, Technologies, Dynamic Model, Railway Transport.

\section{Introduction}

Sorting stations perform their major work on marshaling and breaking up of trains [1-3]. A necessary fleet of wagons for handling the given volume of traffic and delivery speed are highly dependent on them $[4,5]$.

The reduction of wagons residence time at sorting station significantly affects the speed of goods delivery and meeting customer requirements in transportation [1-3, 5, 6]. The availability of inefficient wagons detention awaiting operations in sorting yards deteriorates efficiency, which is unacceptable under market economy conditions. Therefore, there is a need to improve the automation and information system of relevant technological processes at sorting stations $[7,8]$.

To manage the process of marshalling and breaking up of trains, as well as to the reception and delivery of cargoes and other functions it became necessary to create an automated station system in a unified informational railway environment - an automated system of freight traffic operation of Ukrzaliznytsia ASFTO UZ - (e). Substantially similar such systems as Automated System on Sorting Stations Operation (ASSO SS) with various hardware and software complexes have already functioned on railway stations considering various operational specifics [1-3].

The purpose of this article is the study of the degree on automated systems application at sorting stations in Ukraine and the prospects for introducing additional automated modules in sorting stations systems and improving existing ones.

\section{The Interaction of ASFTO UZ - (E)'S Op- erational Process Sample}

In order to reduce the residence time of wagons in sorting station an automated system on sorting stations control ASSC SS was developed and introduced yet in the 70s years of the last century. The author of this development was the Design and Engineering Bureau on the Automated System of Railway Transport Operation of the Ministry of Railways. But in the 90's it already became clear that the Automated System on Sorting Stations Control (ASSC SS) was morally outdated and required modernization. A Ukrainian version of the Automated System on Sorting Stations Operation ASSO SS was developed [9, 10]. It was called an Integrated Electronic Data Interchange System - a sorting station IEDIS SS. The chief developers of the Ukrainian version of the system were specialists of the information and computing center of the Southern Railways. In addition, experts from Lviv and SouthWestern Railways were involved to the development [10-12].

The first version of the Integrated Electronic Data Interchange System (IEDIS SS) functionally did not differ from the previous development, but the introduction of personal computers and interfaces for automated workplaces significantly improved the quality of work of station's employees [2]. A new system significantly accelerated the processing of information. IEDIS SS system was introduced on the railways of Ukraine and its functional component has been continuously improved during operation. This 
system still works at some stations, but the main disadvantage of this system is current incompatibility with modern operating systems, the lack of options for the graphic display.

The control system on the transportation process of station requires effective management of a number of facilities, which is impossible without information about their maintenance, without having a forecast of processes with station facilities that are not yet directly under the control of the station [1-8]. Such information is fully presented in the automated system of freight traffic control ASFTC of UZ. When developing a modern automated control system for the station, the dual task was solved - the preservation of the functions of the ASSC in complex and in interaction with the subsystems of the unified information environment (see Error! Reference source not found.).

By the architecture and functional of automated system of freight traffic operation ASFTO UZ - (e) it was determined that the information on events with control facilities is transferred from automated workplaces of railways employees to the center of transportation process database where certain samples of the transportation process are processed, stored and formed. The system models and subsystems are a virtual mapping of a separate link of the technological process with control facilities, based on information about events with these facilities. A totality of the transportation process samples is formed in order to fulfill the objectives and implement the function of the automated system of freight traffic operation of Ukrzaliznytsia ASFTO UZ - (e). The purpose of this system is total information support for all technological components of the transportation process [3].

The samples are in interaction and strict hierarchy according to the laws of logical control and are created in accordance with the laws, regulations, orders, instructions and so on. A plurality of the transportation process samples forms logical database which ensures the unity of the information environment of the ASFTO UZ - (e). The samples are interrelated by different relations. Each sample is characterized by a set of attributes that are divided into groups and do not intersect with each other - these are the faces of the model, they can contain internal faces.

The composition of faces and attributes for each model is specific, but there may be typical faces and attributes that are characteristic of the base type as a whole. Thus, all models necessarily include the so-called main face that contains the unique identifier of the facility and its life cycle, all model variables contain a face of operations with facilities of this type, all moving facilities have a dislocation face so on.

Relationships between samples are organized either as references from the face of one sample to the identifier of another (facility) object, or by introducing sub faces common to two faces of different samples. The editing of all ASFTO UZ - (e) data to typical samples and the relations between them ensures:

integration of all system data which enables to choose any combination of data on different facilities related by different connections;

- fundamental openness of the database for expansion adding a new sample to the database has almost no effect on the operation of the existing ones;

universalization of the processes on recording and reading data from samples, and also facilitates their maintenance (development, correction of errors, etc.) [4].

All samples of the transportation process interact and exchange information according to the ASFTO UZ - (e) rules.

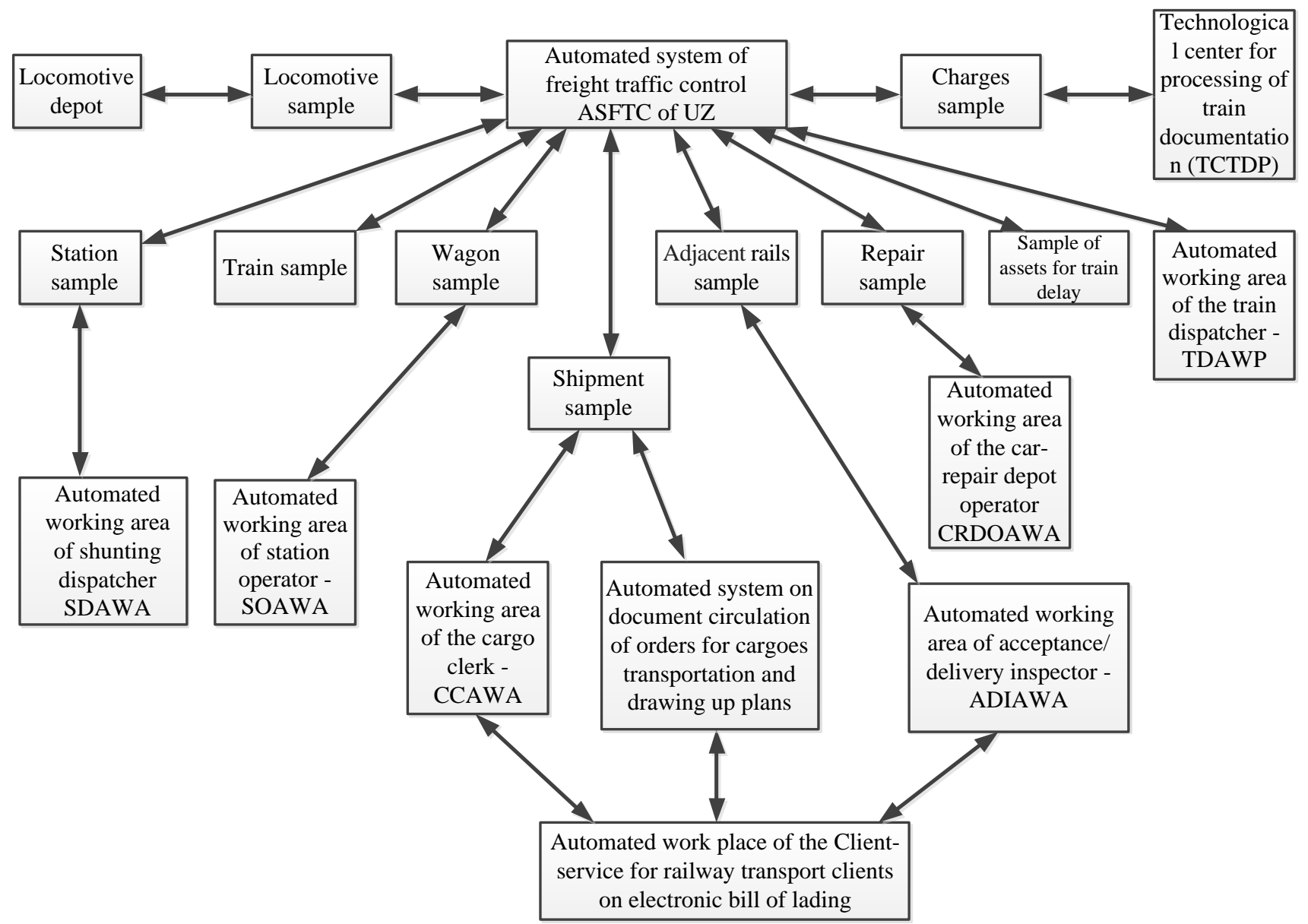

Fig. 1: The interaction of ASFTO UZ - (e)'s operational process sample.

One of these samples in the Automated System on Sorting Stations Operation (ASSO SS) is a dynamic pattern of the station. It is a wagon sample of station tracks for drawing up technological documents of the station. It consists of tables which include variables specified details, the details on operational work of a station. Thus, we can say that the station sample consists of two parts: a 
set of tables describing stationary characteristics and a complex of data on control facilities changing dynamically. This year it is planned to complete the introduction of the dynamic sample of the station and take out of service rather outdated Integrated Electronic Data Interchange System (IEDIS SS). The development of the automated subsystem "Dynamic work of the railway junction" was carried out in compliance with the requirements for building automated information systems for railway transport and capitalizing best skills and advanced practices in this field. Up-to-date software was used in the development of this system. All reliability requirements on software complex were taken into account. Operational capabilities having been achieved while integration of Automated System on Sorting Stations Control (ASSC SS) into ASFTO UZ - (e) afford an opportunity to introduce this system not only at sorting station, but also at those stations where there is a need for this. So the model of wagon stations and tracks is used in the automated working area of a station operator - (SOAWA) as well as in the automated working area of the operator on commercial wagon inspection station CWISOAWA. Further development of the automated subsystem "Dynamic work of the railway junction" is impossible without interaction with the model of access roads, because a large amount of work at all sorting stations is carried out involving feeder lines [5].

Auxiliary profile STC - automated working area of a station employee at Technology Center for train and carriage document processing has been developed to work with the dynamic model of the station on the basis of automated working area. It was here that all the functions for working with automated subsystem "Dynamic work of the railway station junction" were concentrated.

The availability of a database and applied software implement such functions of the AS:

- drawing up and issuing of the marked out consignor

letter;

- $\quad$ drawing up and issuing of sorting letter;

registering for the accumulation of wagons on the tracks

of sorting and receiving-departure yards;

automatic making up of train's consignor letter after train dispatching;

- $\quad$ current planning of a train marshaling on the day periods; analysis of wagon flow volume and identifying violations in plan formation flows;

the possibility of train marshaling according to the delivery period requirements; the possibility of train marshaling in accordance with certain conditions defined by dispatcher's traffic control machine; registering trains and wagons for the availability at stations yards and their processing;

drawing up station's reporting forms; information service of station employees.

During 2013 additional functions and possibilities on the basis of automated working area of a station employee at Technology Center for train and wagon document processing became possible. In particular, the reflection in the main screen of Station Technology Center profile the information on a number of bad-order wagons on the track and giving a full list of additional extended original form; software for registration of acts on the delay of wagons GU23. The implementation in dynamic model of a station the communication between the wagon and the departure (transport document) is of particular importance.

Sorting stations on the railways play a leading role in the transportation process organization. The application of the latest automated systems in sorting stations is constantly increasing every year covering new spheres of operation and control. Currently automated systems totality is the most important element of railway transport operation.

\section{Conclusion}

Existing options for improving sorting station operation by introducing computerization and automated systems as well as devel- oping new ideas to solve this issue have been investigated. It has been shown that consideration of the problem on sorting stations description should be carried out as consideration of complex facility of automation in the design systems of unified automated control systems.

By analyzing up-to-date information systems and technologies being utilized at sorting stations in Ukraine, functional capabilities to be achieved while integration of the "Automated control system" into the ASFTO UZ - (e) have been were achieved.

Further developments of automated subsystem "Dynamic work of the railway junction" requiring scientific researches in solving complex tasks for providing communication between the station wagon and the departure (transport document) have been determined.

It has been highlighted that further development of automated subsystem "Dynamic work of the railway junction" was impossible without interaction with the model of feeder lines after all a large amount of work is done at sorting station involving feeder lines.

\section{References}

[1] Gapanovych, V.A., Shabelnykov, A.N. (2010), Development of automated sorting systems. Zheleznodorozhnyi transport 7, 23-25.

[2] Adadurov, S.E. (2008), Integrated automation system for sorting processes. Zheleznodorozhnyi transport 6, 37-38.

[3] Kyrychenko, H.I. (2013), Kontseptsiia intelektualnoi transportnoi systemy upravlinnia protsesamy dostavky vantazhu. Zaliznychnyi transport Ukrainy 1(1), 37-40.

[4] Grebennik, I., Dupas, R., Lytvynenko, O., Urniaieva, I. (2017), Scheduling Freight Trains in Rail-rail Transshipment Yards with Train Arrangements. International Journal of Intelligent Systems and Applications 9(10), 12-19.

[5] Verma, M., Verter, V., Gendreau, M. (2011), A tactical planning model for railroad transportation of dangerous goods. Transportation Science 45(2), 163-174.

[6] Weihua, G., Tingting, Z., Yuwei, Z. On RFID Application In the Information System of Rail Logistics Center (2013), International Journal of Education and Management Engineering 3(2), 52-58.

[7] Mohamed, H.A.R.A (2014), Proposed Model for Radio Frequency Systems to Tracking Trains via GPS (The Study for Egyptian National Railways). International Journal of Intelligent Systems and Applications, 6(4), 76-83.

[8] Chandrappa, S., Dharmanna, L., Shubhada, V.P., Meghana, N.U. (2017), Automatic Control of Railway Gates and Destination Notification System using Internet of Things (IoT). International Journal of Education and Management Engineering 7(5) 45-55.

[9] Kyrychenko, H. I. (2017), Creation principles of intelligent automated delivery management systems at the railway. Science and Transport Progress. Bulletin of Dnipropetrovsk National University of Railway Transport 2 (68), 46-55.

[10] Bashlaiev, V. K., Tseitlin, S. Y., Velykodnyi, V. V. (2007). About the network of automated control system creating of Ukrainian freight transport. Science and Transport Progress 17, 18-21.

[11] Kyrychenko, H. I., Strelko, O. H., Berdnychenko, Yu. A., Petrykovets, O. V., Kyrychenko O. A. (2016), Scenarios modeling of cargo movement in the supply chains, Transport systems and transportation technologies 12: 32-37.

[12] Kozachenko, D. M., Vernyhora, R. V., Horbova, O. V. (2014). Methods of data collection on the functioning of the railway stations. Transport Systems and Transportation Technologies 8, 58-64 https://doi.org/10.15802/tstt2014/38087 